\title{
CORRUPTION IN HIGHER EDUCATION OF UKRAINE
}

\author{
Oksana Duchak \\ Faculty of Social Sciences, The John Paul II Catholic University of Lublin \\ Al. Racławickie 14, 20- 950 Lublin, Poland \\ E-mail address: oksana.duchak@gmail.com
}

Keywords: corruption; higher education; youth

\begin{abstract}
In the case of corruption, the young generations' obtainment of core ethical values may be undermined during the formative years that are critical to the promotion of integrity and accountability in a given society. The results may be widespread, long-lasting and severe.

In the article are elucidated characteristics of corruption, aspects of the interaction between gender and corruption in higher education, negative effects of corruption.

One function of education is to purposefully teach the young how to behave in the future. If the education system is corrupt, one can expect future citizens to be corrupt as well.[9, p. 3].
\end{abstract}

\section{INTRODUCTION.}

In the case of corruption, the young generations' obtainment of core ethical values may be undermined during the formative years that are critical to the promotion of integrity and accountability in a given society. The results may be widespread, long-lasting and severe. Corruption has negative influence on the price, volume and quality of education services, affecting learning outcomes, reducing public confidence [10]. It is worth to mention the professional certification, corruption in education can have devastating effect for public health and safety by allowing incompetent doctors and teachers to purchase their diplomas [3].

In the article are elucidated characteristics of corruption, aspects of the interaction between gender and corruption in higher education, negative effects of corruption.

\section{CHARACTERISTICS OF CORRUPTION.}

The word corruption comes from the Latin word corruptio, which in Medieval Latin means a moral decay, wicked behavior, badness, rottenness. Forms of corruption include bribery, fraud, extortion, ghost instructors, plagiarism, research misconduct [14, p.4.].

The widespread corruption in higher education in Ukraine is a proven fact. It has plagued academia and includes bribery and nepotism in admissions, grading and graduation, as well as diploma mills, fraud, embezzlement and gross waste of the state funds.

Corruption is able to generate in the particular context of higher education when parties to a corrupt transaction have complementary roles, interests and capabilities. Many sources testify how professors are chronically underpaid to such an extent that academics have to take additional jobs in order to earn money [17, p. 83]. Students have to navigate an elaborate and highly opaque system. For example, they are required to pass a large variety of subjects to proceed from one academic year to the next. Informal payments can be used to guarantee the necessity passes to proceed to the next academic year [13, p. 22].

It is significant to analyze and tackle corruption in education because it sets negative standards and norms that shape the behavior of new generation Corruption in education hinders economic and social development by affecting access to and quality of education. Evidence has shown that societies with high levels of corruption have low-quality education and poor educational 
results of students - funds for education are stolen, teachers (and hence students) are not well prepared, and schools are built with low-quality materials. [13, p. 10].

\section{GENDERED ASPECTS OF CORRUPTION.}

Ukraine has been described as having one of the highest levels of gender segregation in its system of education, compared with other European countries. [19, p.12]. Corruption in education occurs in a context in which men dominate the senior-level positions of higher education institutions and women are over-represented in academic and general support staff roles. The levels occupied by different genders in the hierarchy of academic institutions shape their different experiences of corruption. Institutional stereotyping is one factor contributing to gender disparity. If there is a choice to be made within a higher educational establishment between a male and female candidate to fill an administrative position, the position will most likely be given to the male due to gendered-biased stereotypes. [7, p. 13-14].

Both men and women interviewed observed that women face more resistance in advancing into higher-level academic, administrative and managerial positions. For men, it appears sufficient to have a relevant academic degree and appropriate connections in order to secure appointments. Female respondents find that appointments require not merely relevant degrees and connections but often bribes of various forms. [20].

The disproportionate distribution of gender in the organizational hierarchy of education institutions therefore means that different genders will typically be exposed of different types of corruption opportunities. [7, p. 11]. At the level of academic faculty, the distribution is about equal between men and women. The experiences and perceptions of women and men are therefore more easily comparable at this level. Research show that men are found to be more likely to initiate an offer of money, goods or services in the education sector and more likely to contribute to "charity funds" purporting to benefit the education institution from which they were seeking services. [7, $p$. 19].

According to data from Transparency International's Global Corruption Barometer, women around the world were more likely to judge institutions as "very corrupt" or "extremely corrupt" and to agree that corruption affects their lives to a large extend. [16, p. 8-9].

\section{NEGATIVE EFFECTS OF CORRUPTION.}

Effects of corruption are particularly insidious in the education sector. By blowing the principles of educational integrity, corruption begins a pattern of inadequacy in which underqualified teachers continually produce under-qualified graduates. Corruption in education teaches corruption. A corrupt education system will produce "entire generations of youth [who] are miseducated-by example-to believe that personal success comes not through merit and hard work, but through favoritism, bribery, and fraud". [2, p. 3] In a result the same thoughts may appear in the process of students' future work.

Corruption hurt students by: a). Undermining educational quality; b). providing inequitable access to educational services; c). reducing educational quality; d). diminishing student optimism about fulfilling their potential; e). limiting career prospects; f). devaluating degrees.[1, p. 16]

Corruption in education has severe consequences: a). A high drop-out rate, which increases at high levels of poverty; b). low quality teaching, leading to poor achievements; c). a system susceptible to adverse political, religious and ethnic influence; d). deepened inequality between rich and poor, preventing entire generations from pursuing a meaningful future.[4, p. 4]

\section{CONCLUSION}

Corruption not only distorts access to education but also affects the quality of education and the reliability of academic research findings. It is important to analyze and tackle corruption in education because it sets negative standards and norms that shape the behavior of new generation. 
Different genders have different experiences with corruption in higher education. Men dominate at senior levels and have greater opportunity to engage in the types of corruption enjoyed by senior-level officials. Women are over- represented in the lower levels of the organization and accordingly tend to engage in smaller-scale incidences of corruption.[7, p. 15]

Effects of corruption are particularly insidious in the education sector. By eroding the principles of educational integrity, corruption begins a pattern of inadequacy in which underqualified teachers continually produce under-qualified graduates.

MSc. Oksana Duchak - PhD candida te at the Faculty of Social Sciences in general Pedagogy at the John Paul II Catholic University of Lublin in Poland. Scientific interests: family studies, psychology, media studies, methods of learning foreign languages, school pedagogy. Email: oksana.duchak@gmail.com

\section{References}

[1] Addressing Corruption in Education, USAID, EDC, Transparent Education Network, 2012, p. 7- 16.

[2] Chapman. D, Corruption and the Education Sector, Management Systems International, November 2002, p.

[3] Corruption in Ukraine. Comparative Analysis of National Surveys: 2007-2009, Millenium Challenge Corparation (MCC) Threshold Country Plan in cooperation with Kyiv International Institute of Sociology (KIIS), executive partner in Ukraine.

[4] Corruption in the education sector, Anti- Corruption Resource Centre, CHR. Michelsen Institute, U4 Issue 4, 2006, p. 4.

[5] Chapman D, Corruption and the education sector. Sectoral Perspectives on Corruption, Washington, D. C., USAID. Prepared by MSI, sponsored by USAID, DCHA/DG, 2002, p. 3.

[6] Fighting corruption in the education sector, Methods, tools and good practices, United Nations Development Program, October 2011, New York, p. 20.Global Corruption Report: Education, Transparency International, 2013.

[7] Gender aspects of corruption in higher education in Ukraine, The Institute of Applied Humanitarian Research, p. 11, 13- 15.

[8] Hallak J, Poisson M, Ethics and corruption in education: Results from the Expert Workshop held at the IIEP, November 2001, p. 28- 29. Forum on Education, 15, International Institute on Educational Planning, IIEP, p. 16.

[9] Heyneman. S., Anderson K., Nuraliyeva N, The cost of corruption in higher education. Comparative Educational Review, 52 (1), 1- 25, p. 3.

[10] U4 Anti- Corruption Resource Centre, Gender, Corruption and Education, U4 Expert Answer, 14 July 2009.

[11] Meier B, Corruption in Education: An Introduction. In: B. Meier, M. Griffin. (eds.), Stealing the Future: Corruption in the Classroom, 2005, p. 7.

[12] Osipian A., Higher Education Corruption in Ukraine: Opinions and Estimates, International Higher Education, The Boston college center for international higher education, n. 49, 2007, p. 21.

[13] Osipian A., Higher Education Corruption in Ukraine as Reflected in the Nation's Media, Vanderbilt University Working Paper, p. 22. 
[14] Osipian A., Corruption and Reform in Higher Education in Ukraine, Canadian and International Education, Education canadienne et international, 38 (2), p. 104- 122, s. 3.

[15] 15 Poisson M., Corruption and education, International Academy of Education, International Institute for Educational Planning, 2010, p. 11.

[16]Progress of the World's Women: Who Answers to Women? Gender and Accountability, UNIFEM, New York, United Nations Fund for Women, 2008/2009, p. 8-9.

[17]Round J. and Rodgers. P, The problems of Corruption in post-Soviet Ukraine, International Journal of Sociology, vol. 39, no. 2, summer 2009, p. 83.

[18] Shaw P., The Determinants of Educational Corruption: The Case of Ukraine, July 31, 2009, p. 3.

[19] Valentova M. et. al, Occupational Gender Segregation in the light of the Segregation in Education: A Cross- National Comparison, IRISS Working Papers, April 2007, p. 12.

[20]Гендерний аналіз корупџійних практик на ринку пращуі, Institute of Applied Humanitarian Research, 2009.

[21]Сисоєва. С. О, Освіта як об'єкт дослідження, Шлях освіти, в: Науково-методичний журнал, 2, 2011, p. 5-11. 